\title{
Chemical Analysis of the Essential Oil from Siparuna echinata (Kunth) A. DC. (Siparunaceae) of Ecuador and Isolation of the Rare Terpenoid Sipaucin A
}

\author{
Jessica García $^{1}$, Gianluca Gilardoni ${ }^{1}\left(\mathbb{D}\right.$, Nixon Cumbicus $^{2}$ and Vladimir Morocho ${ }^{1, *}$ (i) \\ 1 Departamento de Química y Ciencias Exactas, Universidad Técnica Particular de Loja (UTPL), Loja 1101608, \\ Ecuador; jkgarcia3@utpl.edu.ec (J.G.); gianluca.gilardoni@gmail.com (G.G.) \\ 2 Departamento de Ciencias Biológicas, Universidad Técnica Particular de Loja (UTPL), Loja 1101608, \\ Ecuador; nlcumbicus@utpl.edu.ec \\ * Correspondence: svmorocho@utpl.edu.ec; Tel.: +593-7-3701440
}

Received: 19 December 2019; Accepted: 30 January 2020; Published: 4 February 2020

\begin{abstract}
The phytochemical research on the species Siparuna echinata, collected in the Province of Loja (Ecuador), led to the isolation of a rare sesquiterpenoid, called Sipaucin A. The structure was confirmed by nuclear magnetic resonance (NMR) and mass spectrometry (MS). Furthermore, the essential oil of the fruits was obtained by hydrodistillation and analyzed by gas chromatography, coupled to mass spectrometry (GC-MS) and flame ionization detector (GC-FID). Twenty-seven compounds were identified in a polydimethylsiloxane column (DB-5ms) and nineteen in a polyethylene glycol column (HP-INNOWax). Major compounds were $\alpha$-pinene (24.3\%, 20.3\%), $\beta$-pinene $(21.7 \%, 22.7 \%)$, $\beta$-myrcene $(11.3 \%, 14.8 \%)$, limonene $(10.0 \%, 11.3 \%)$, cis-ocimene $(8.5 \%, 8.1 \%)$, and trans-ocimene $(8.9 \%, 8.4 \%)$. In addition to the chemical analysis, the essential oil was submitted to enantioselective analysis of two major chiral monotherpenes, determining an enantiomeric excess of $100.0 \%$ for $(+)-\alpha$-pinene and $6.7 \%$ for $(+)-\beta$-pinene.
\end{abstract}

Keywords: Siparuna echinata; essential oil; enantioselective analysis; Sipaucin A; Ecuador

\section{Introduction}

The geographic location of Ecuador, together with its geological features, makes this region one of the richest of the world in biodiversity. According to the WCMC (World Conservation Monitoring Center) of the United Nations, Ecuador is considered among the 17 megadiverse countries, counting with about $10 \%$ of the entire world plant species [1,2].

Every year, new plants are discovered and classified by botanists, while most of the known ones have never been studied so far for their metabolic composition. This fact converts Ecuador to an invaluable source of potentially new molecules of biological and pharmaceutical interest [3].

For all these reasons, the authors have been carrying on, since many years, the chemical description of the secondary metabolite profile of never studied species in Ecuador, especially in the Province of Loja. These studies are mainly focused on chemistry, with the structure elucidation of natural products, the analysis of new essential oils, and the description of biological activities [4-7].

In this work, we focused on some new terpenoids called Sipaucins, recently discovered in the species Siparuna pauciflora and described so far only once in literature [8]. Furthermore, Siparuna spp. often produce a volatile fraction that appeared to be abundant in fruits of $S$. echinata, justifying the study of the essential oil (EO).

The Siparunaceae, previously considered as part of the Monimiaceae, include two genera: Glossocalix and Siparuna. They have been reported for the presence of sesquiterpene volatile fractions, showing the property of inducing cell apoptosis [9-11]. 
The genus Siparuna includes 235 plant species distributed in tropical regions of Central and South America [12]. It is characterized by biosynthesizing interesting secondary metabolites such as sesquiterpenes [13], flavonoids [13,14], and isoquinoline alkaloids [15,16], found in plant extracts and in essential oils, with a broad spectrum of pharmacological properties, such as: antibacterial, antimalarial, and antileishmaniasis [17].

Siparuna echinata is a native shrub of the Andean region, widespread from Colombia to Bolivia. It is known with the synonyms of Citrosma apicifera Tul., Citrosma buddleiifolia Benth., Citrosma echinata Kunth, Siparuna apicifera (Tul.) A. DC., Siparuna buddleiifolia (Benth.) A. DC., Siparuna holtonii A. DC., Siparuna killipii Perkins, Siparuna olivaceo-velutina Sleumer, Siparuna phaneroneura Standl., and Siparuna valenzuelae Cuatrec $[18,19]$.

In Ecuador, it grows in the provinces of Bolivar, Carchi, Chimborazo, Cotopaxi, Imbabura, Morona Santiago, Napo, Pichincha, and Sucumbíos, between 1800 and $3650 \mathrm{~m}$ above sea level [14]. In this study, to the best of the authors' knowledge, this species has been described for the first time in the Province of Loja. Commonly known as "limoncillo", it is used by infusion of fruits and leaves in traditional medicine to treat digestive disorders and rheumatisms [2-19].

\section{Results}

\subsection{Characterization of Sipaucin A}

The ethyl acetate (EtOAc) extract of S. echinata led to the isolation and characterization of Sipaucin A. After removing chlorophyll, the extract was submitted to gas chromatography-mass spectrometry (GC-MS) analysis, based on a single ion monitoring (SIM) method, that was prepared according to the ions described in literature for the electron impact MS (EIMS) spectra of Sipaucins A-C [8]. The resulting chromatogram is shown in Figure 1.

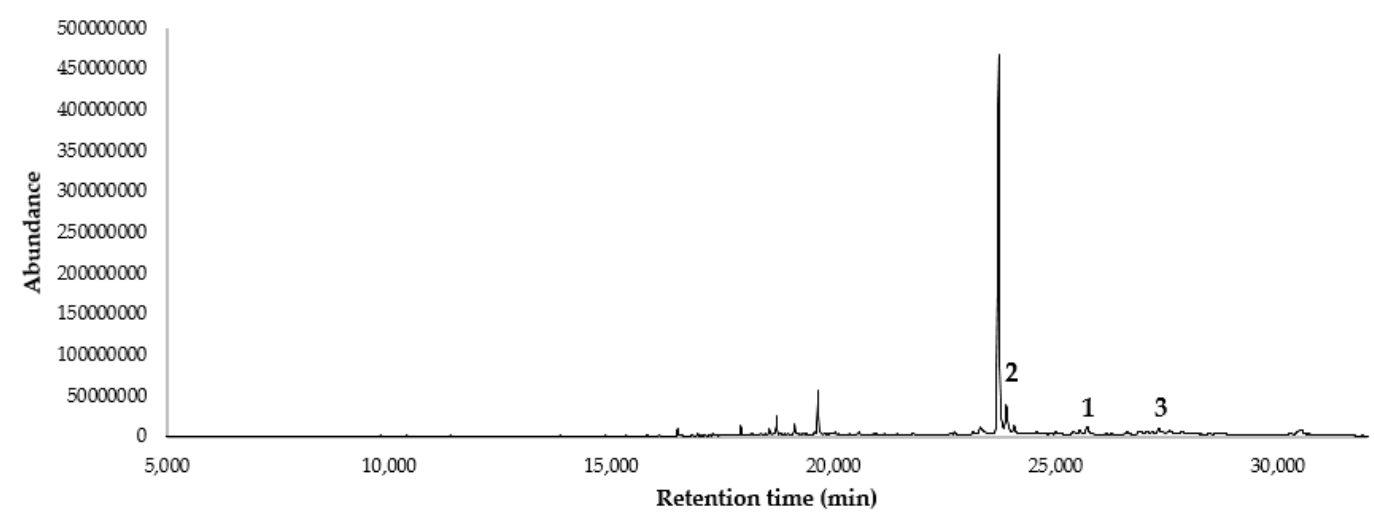

Figure 1. Selective gas chromatography-mass spectrometry (GC-MS) analysis (single ion monitoring, SIM) for Sipaucins ions in the ethyl acetate extract of Siparuna echinata. 1, possible peak of Sipaucin A; 2, possible peak of Sipaucin B; 3, possible peak of Sipaucin C.

Figure 1 evidenced the presence of some metabolites consistent with the ionization pattern of Sipaucins. The preparative fractionation of the extract achieved only Sipaucin A (Figure 2) with $0.3 \%$ yield ( $w / w$ referred to chlorophyll-free mixture). It was submitted to NMR spectroscopy, resulting in data identical to those from literature [8]. 


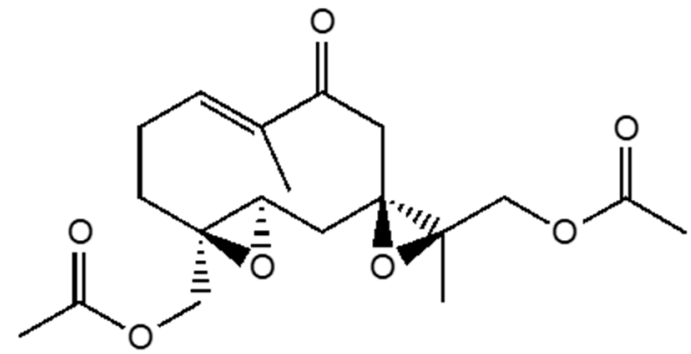

Figure 2. Structure of Sipaucin A.

\subsection{Essential Oil Analysis}

The EO distillation produced a yield of $1.09 \pm 0.10 \%$ ( $w / w$, referred to dry fruits). In the chemical analysis of the $\mathrm{EO}$ of $S$. echinata, a total of twenty-seven and nineteen compounds were identified and quantified, respectively, with DB-5ms and HP-INNOWax columns. The EO was mainly composed of monoterpene hydrocarbons, corresponding to $84.8 \%$ and $89.7 \%$ of the total composition, respectively. Major compounds were $\alpha$-pinene $(24.3 \%, 20.3 \%), \beta$-pinene $(21.7 \%, 22.7 \%), \beta$-myrcene $(11.3 \%, 14.8 \%)$, limonene $(10.0 \%, 11.3 \%)$, cis-ocimene $(8.5 \%, 8.1 \%)$, and trans-ocimene $(8.9 \%, 8.4 \%)$. The chemical composition of the EO is shown in Table 1 according to the elution order in DB-5ms.

Table 1. Chemical composition of the essential oil distilled from Siparuna echinata.

\begin{tabular}{|c|c|c|c|c|c|c|c|c|c|}
\hline \multirow{2}{*}{ Compounds } & \multicolumn{4}{|c|}{ DB-5ms } & \multicolumn{4}{|c|}{ HP-INNOWax } & \multirow{2}{*}{$\begin{array}{l}\text { Reference } \\
\text { Literature }\end{array}$} \\
\hline & LRI $^{a}$ & LRI $^{b}$ & $\%$ & $\sigma$ & LRI $^{a}$ & LRI & $\%$ & $\sigma$ & \\
\hline$\alpha$-pinene & 932 & 932 & 24.3 & 2.36 & 1065 & 1076 & 20.3 & 2.69 & [20] \\
\hline camphene & 947 & 946 & 0.9 & 0.18 & 1083 & 1092 & 0.8 & 0.43 & [21] \\
\hline sabinene & 970 & 969 & 1.1 & 0.02 & 1120 & 1125 & 1.4 & 0.07 & [21] \\
\hline$\beta$-pinene & 976 & 974 & 21.7 & 1.43 & 1108 & 1103 & 22.7 & 1.70 & [22] \\
\hline$\beta$-myrcene & 989 & 988 & 11.3 & 2.34 & 1165 & 1161 & 14.8 & 2.57 & [22] \\
\hline limonene & 1027 & 1024 & 10.0 & 3.55 & 1199 & 1194 & 11.3 & 3.94 & [22] \\
\hline cis-ocimene & 1036 & 1032 & 8.5 & 1.77 & 1235 & 1228 & 8.1 & 1.40 & [23] \\
\hline trans-ocimene & 1045 & 1044 & 8.9 & 5.43 & 1250 & 1244 & 8.4 & 5.10 & [23] \\
\hline perillene & 1098 & 1102 & 0.1 & 0.03 & - & - & - & - & - \\
\hline linalool & 1101 & 1095 & 0.6 & 0.60 & 1549 & 1546 & 0.8 & 1.04 & [22] \\
\hline nopinone & 1138 & 1135 & 0.1 & 0.03 & - & - & - & - & - \\
\hline trans-pinocarveol & 1140 & 1135 & 0.4 & 0.29 & 1643 & 1642 & 0.7 & 0.63 & [24] \\
\hline cis-verbenol & 1146 & 1137 & 0.4 & 0.52 & 1668 & 1663 & 0.5 & 0.69 & [25] \\
\hline myrtenol & 1196 & 1194 & 0.1 & 0.05 & 1789 & 1794 & 0.3 & 0.13 & [26] \\
\hline 6-undecanol & 1284 & 1284 & 0.2 & 0.10 & 1570 & - & - & - & - \\
\hline 2-undecanone & 1294 & 1284 & 0.2 & 0.13 & 1593 & 1598 & 0.4 & 0.60 & [27] \\
\hline decanoic acid & 1376 & 1364 & 0.5 & 0.68 & - & - & - & - & - \\
\hline$\beta$-elemene & 1387 & 1389 & 0.2 & 0.13 & - & - & - & - & - \\
\hline trans-caryophyllene & 1415 & 1417 & 0.2 & 0.09 & 1580 & 1580 & 0.3 & 1.30 & [28] \\
\hline$\alpha$-humulene & 1451 & 1452 & 0.2 & 0.13 & - & - & - & - & - \\
\hline germacrene D & 1477 & 1480 & 1.4 & 0.45 & 1687 & 1680 & 1.2 & 0.22 & [23] \\
\hline$\beta$-selinene & 1484 & 1489 & 0.3 & 0.20 & 1703 & 1708 & 0.4 & 0.50 & [29] \\
\hline 2-tridecanone & 1496 & 1495 & 0.4 & 0.22 & 1808 & 1815 & 0.6 & 0.81 & [30] \\
\hline germacrene $\mathrm{A}$ & 1502 & 1508 & 0.3 & 0.12 & 1748 & 1744 & 0.7 & 0.98 & [23] \\
\hline germacrene B & 1554 & 1559 & 1.9 & 0.20 & 1814 & 1811 & 2.1 & 0.78 & [31] \\
\hline caryophyllene oxide & 1578 & 1582 & 0.3 & 0.16 & - & - & - & - & - \\
\hline$\beta$-eudesmol & 1651 & 1649 & 0.2 & 0.07 & - & - & - & - & - \\
\hline Monoterpene hydrocarbons & & & 86.7 & & & & 87.8 & & \\
\hline Oxygenated monoterpenes & & & 1.7 & & & & 2.3 & & \\
\hline Sesquiterpene hydrocarbons & & & 4.5 & & & & 4.7 & & \\
\hline Oxygenated sesquiterpenes & & & 0.5 & & & & 0.0 & & \\
\hline Others & & & 1.3 & & & & 1.0 & & \\
\hline Total identified & & & 94.7 & & & & 95.8 & & \\
\hline
\end{tabular}




\section{Enantioselective GC Analysis}

The enantioselective analysis of the EO was carried out with a $\beta$-cyclodextrine-based GC column, coated with 2,3-diacethyl-6-tert-butylsilyl- $\beta$-cyclodextrin as chiral selector. The analysis was performed on two of the four major compounds ( $\alpha$-pinene and $\beta$-pinene), with myrcene being a non-chiral molecule and limonene enantiomers not being separable with this chiral selector. The results of the enantioselective analysis are shown in Table 2, expressed as enantiomeric distribution and enantiomeric excess (ee), and Figure 3.

Table 2. Enantioselective analysis of S. echinata essential oil on diacethyl terbutylsilyl- $\beta$-cyclodextrin column.

\begin{tabular}{cccc}
\hline LRIs & Enantiomers & Enantiomeric Distribution (\%) & ee (\%) \\
\hline 858 & $(+)-\alpha$-pinene & 100.0 & 100.0 \\
896 & $(+)-\beta$-pinene & 53.4 & 6.7 \\
898 & $(-)-\beta$-pinene & 46.6 & \\
\hline
\end{tabular}

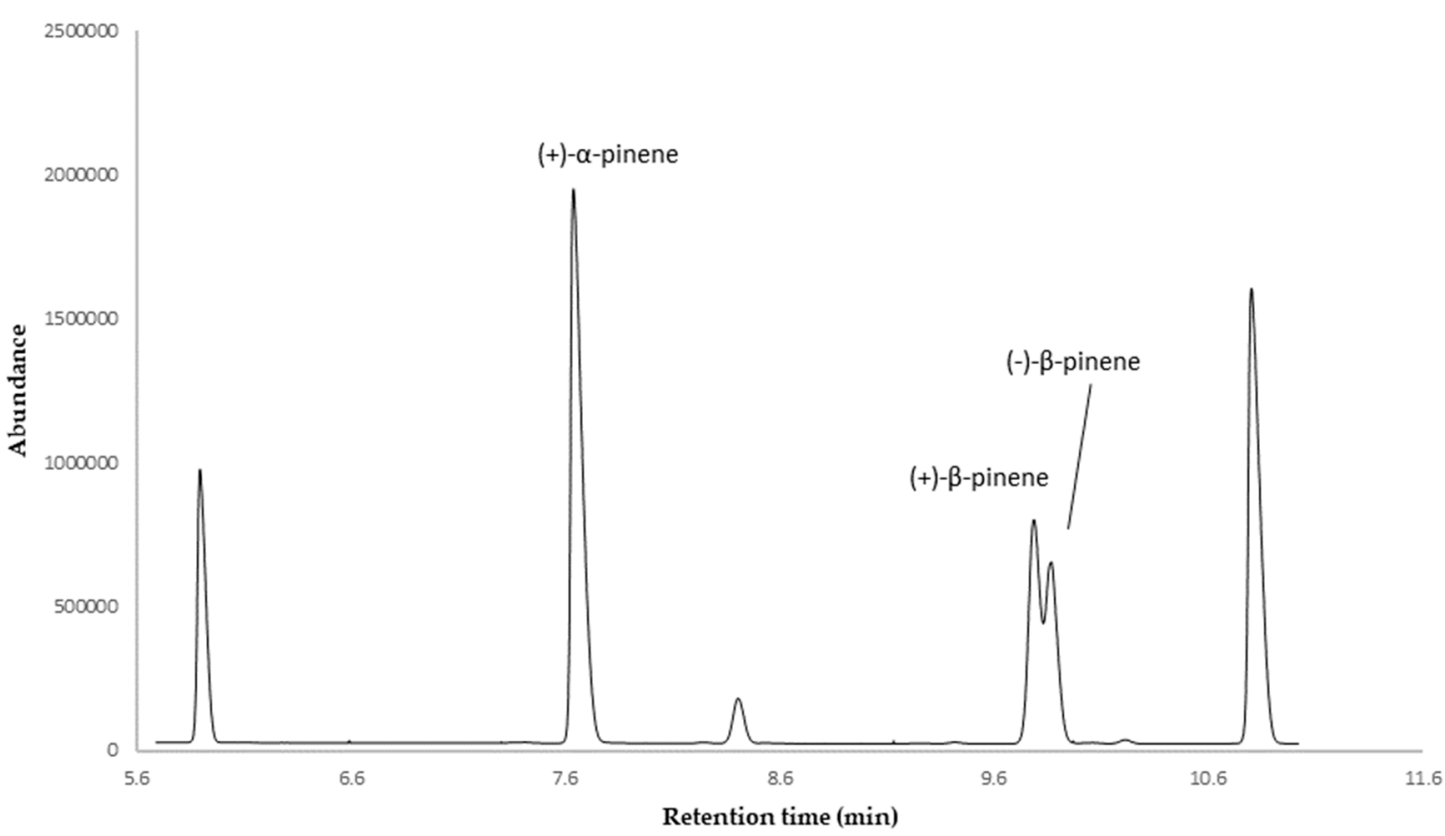

Figure 3. Enantioselective analysis of essential oil (EO) of S. echinata on diacethyl terbutylsilyl- $\beta$ cyclodextrin column.

\section{Discussion}

Sipaucins are rare sesquiterpenoids that have been described for the first time in 2003 in $S$. pauciflora [8] and not yet found in other species until now. As these metabolites could be characteristic of Siparuna genus, we decided to selectively search for them in the ethyl acetate extract, performing a single ion monitoring (SIM) GC-MS analysis. In the chromatogram of Figure 1, all the peaks consistent with the selected ions are shown. In particular, peak 1,2, and 3 represent compounds whose ions and relative abundance are, respectively, compatible with Sipaucin A, B, and C. It should be underlined that these peaks are quite evident only in SIM analysis and splitless injection, demonstrating that they actually correspond to minor constituents of the extract. This fact could justify the low yield of Sipaucin A and the non-obtention of other Sipaucins. The presence of more than three peaks, all being compatible with this family of metabolites suggests that other new related compounds are possibly produced by S. echinata, though there is no evidence of the certain presence of these molecules in the extract.

Concerning the chemical composition of the volatile fraction, the EOs from other species of genus Siparuna were mainly based on sesquiterpenes: S. aspera and S. macrotepala presented as major 
compounds germacrene D $(23.2 \%, 42.1 \%)$, bicyclogermacrene $(7.8 \%, 11.8 \%)$, and $\alpha$-pinene $(7.0 \%$, $1.8 \%)$ [34], while in the essential oil of S. eggersii the principal components were epicurzerenone $(29.9 \%)$, germacrone (10.5\%), and caryophyllene oxide (29.0\%) [23]. On the other hand, our EO was mainly composed of monoterpenes, with $\alpha$-pinene (24.3\%), $\beta$-pinene (21.7\%), $\beta$-myrcene (11.3), and limonene $(10.0 \%)$ being major constituents.

Nevertheless, germacrenes are constantly present, which is an important factor, as they are structurally and biogenetically related [35] to Sipaucin A.

The enantioselective analysis showed (+)- $\alpha$-pinene as a pure enantiomer, while $(+)-\beta$-pinene evidenced enantiomeric excess.

\section{Materials and Methods}

\subsection{General Information}

The NMR spectra were performed in a Varian spectrometer (Walnut Creek, CA, USA, $400 \mathrm{MHz}$ for ${ }^{1} \mathrm{H}$ and $100 \mathrm{MHz}$ for ${ }^{13} \mathrm{C}$ ) in $\mathrm{CDCl}_{3}$ (from Sigma Aldrich, Saint Louis, MO, USA). The chemical shifts were reported in $\delta(\mathrm{ppm})$, relative to the signal of tetramethylsilane (TMS) and the coupling constants $(J)$ in $\mathrm{Hz}$.

The GC-MS analyses were performed on an Agilent Technologies (Wilmington, DE, USA) 6890N gas chromatograph coupled to a mass spectrometer detector (MSD) Agilent Technologies 5973N. For both GC-MS and gas chromatography-flame ionization detector (GC-FID) analyses, the instrument was equipped with a DB-5ms Agilent 122-5532 column (length $30 \mathrm{~m}, 0.25 \mathrm{~mm}$ internal diameter and $0.25 \mu \mathrm{m}$ stationary phase thickness) and a HP-INNOWax column (length $30 \mathrm{~m}, 0.25 \mathrm{~mm}$ internal diameter and $0.25 \mu \mathrm{m}$ stationary phase thickness). The MSD was equipped with an electron impact ion source, operating at $70 \mathrm{eV}$. The ion analyzer was operated in SCAN mode for the EO analysis (35-350 amu) and SIM mode for Sipaucins' detection.

The enantioselective GC analysis was carried out with an enantioselective capillary column, based on 2,3-diacethyl-6-tert-butylsilyl- $\beta$-cyclodextrin as chiral selector $(25 \mathrm{~m} \times 0.25 \mathrm{~mm} \times 0.25 \mu \mathrm{m}$, purchased from MEGA, Milan, Italy), installed in the same GC-MS system. Helium was used as carrier gas (Indura, Guayaquil, Ecuador).

Silica gel 60 (Merck KGaA, Darmstadt, Germany, from 0.063 to $0.200 \mathrm{~mm}$ ) and RP-18 (Merck 40-63 $\mu \mathrm{m}$ ) were used as stationary phases for column chromatography (CC). Normal phase thin layer chromatography (TLC) plates, with fluorescence indicator at $254 \mathrm{~nm}$, were purchased from Sigma-Aldrich.

After exposure to UV light (254 and $366 \mathrm{~nm}$ ), the plates were treated with a mixture of sulfuric acid and vanillin as chromatic reagent for spot detection.

All organic solvents for TLC and CC were technical grade, purchased from Relubquim Cia. Ltd.a. (Quito, Ecuador), and distilled before using. All solvents for GC, alkanes for linear retention indices (LRI), and the internal standard ( $n$-nonane) were of analytical grade (purity $>99 \%$ ), from Sigma-Aldrich. The calibration standard was isopropyl caproate, obtained in the authors' laboratory by synthesis and purified to $98.8 \%$ (GC-FID purity).

\subsection{Plant Material}

The aerial parts of S. echinata were collected on May 2017 in the sector Guchanama, canton of Celica, province of Loja, with coordinates $4^{\circ} 05^{\prime} 31^{\prime \prime} \mathrm{S}$ and $79^{\circ} 57^{\prime} 18^{\prime \prime} \mathrm{W}$, at $2220 \mathrm{~m}$ above sea level. The botanical sample was identified by one of the authors (N.C.) and deposited in the herbarium of the Universidad Técnica Particular de Loja, with voucher number VMZ-120. The samples were collected under governmental permission (MAE-DNB-CN-2016-0048). 


\subsection{Extraction and Isolation of Sipaucin A}

The dried leaves of S. echinata $(730 \mathrm{~g})$ were extracted by Soxhlet with ethyl acetate (EtOAc) for 10 h. Soxhlet extraction was preferred to static maceration because, in a previous essay, the two methods were compared on analytical samples of plant material, producing the same chromatographic profile with higher yield in favor of Soxhlet. A yield of $27.4 \%(w / w)$ was obtained.

An amount of $10 \mathrm{~g}$ of extract was eluted on C-18 reversed phase, in order to completely remove chlorophylls. The elution was performed isocratically with a mixture of methanol/water in the ratio of 85:15, producing $5 \mathrm{~g}$ of chlorophyll-free extract. To prove the presence of Sipaucins, $20 \mathrm{mg}$ of chlorophyll-free extract was dissolved in $1 \mathrm{~mL}$ of dichloromethane and the solution $(1 \mu \mathrm{L})$ was injected in splitless mode in GC-MS (DB-5ms column). The elution was conducted with a thermal gradient, according to the following program: the initial temperature was $50^{\circ} \mathrm{C}$ maintained for $3 \mathrm{~min}$, followed by a thermal gradient of $10{ }^{\circ} \mathrm{C} / \mathrm{min}$ until the temperature of $250{ }^{\circ} \mathrm{C}$, that was maintained for $17 \mathrm{~min}$. The injector temperature was set at $250^{\circ} \mathrm{C}$ and the carrier gas (helium) at $1 \mathrm{~mL} / \mathrm{min}$ (constant flow). The SIM method is described in Table 3.

Table 3. SIM/MS method for the detection of Sipaucins in the extract.

\begin{tabular}{cccccc}
\hline & \multicolumn{2}{c}{ Sipaucin A } & \multicolumn{2}{c}{ Sipaucin B } & \multicolumn{2}{c}{ Sipaucin C } \\
\hline Ion $^{\text {a }}$ & Dwell Time (ms) & Ion $^{\text {a }}$ & Dwell Time $(\mathrm{ms})$ & Ion $^{\text {a }}$ & Dwell Time (ms) \\
\hline 109 & 25 & 91 & 25 & 109 & 25 \\
293 & 25 & 106 & 25 & 125 & 25 \\
307 & 25 & 124 & 25 & 180 & 25 \\
366 & 25 & 142 & 25 & 293 & 25 \\
$\left(\mathrm{M}^{+}\right)$ & & & & 366 & \\
& & 254 & 25 & $\left(\mathrm{M}^{+}\right)$ & \\
& & 233 & 25 & \\
& & 272 & 25 & & \\
& & 290 & 25 & & \\
& 332 & 25 & & \\
& & &
\end{tabular}

${ }^{\text {a }}$ Electron impact ions according to [8].

The preparative purification by $\mathrm{CC}$ was performed from $2 \mathrm{~g}$ of chlorophyll-free extract. Silica gel $(200 \mathrm{~g})$ was packed in a glass column $(50 \mathrm{~mm} \times 800 \mathrm{~mm})$, and the extract was eluted in fractions with varying ratios of eluent mixture hexane/EtOAc from $100 \%$ hexane until 100\% EtOAc. A total of 14 fractions were obtained (JK01-JK14), according to TLC profiles.

The fraction JK11 (134 mg) was further purified by CC in isocratic conditions, eluting with a mixture of hexane/EtOAc in the ratio of 95:5. A total of five fractions were collected according to TLC and subfraction $4(15 \mathrm{mg})$ was subjected to preparative TLC. The plate was eluted with hexane/EtOAc in the ratio of 6:4, yielding $3 \mathrm{mg}$ of pure Sipaucin A.

The metabolite was characterized by NMR spectroscopy, resulting in data identical to those from literature (see Supplementary Material, Figures S1 and S2 and Table S1).

\subsection{Analysis of the $E O$}

The volatile fraction was obtained by separately hydrodistilling four amounts of $265 \mathrm{~g}$ of dried fruits for $5 \mathrm{~h}$, using a Clevenger type glass apparatus. The essential oil was collected and dried over anhydrous sodium sulfate and stored at $4{ }^{\circ} \mathrm{C}$ until further analysis.

The analytical samples were prepared by diluting an exactly weighed amount of essential oil (corresponding to $10 \mu \mathrm{L}$ ) with $1 \mathrm{~mL}$ of internal standard solution, previously prepared by 
diluting $0.7 \mathrm{mg}$ of $n$-nonane to a total volume of $10 \mathrm{~mL}$ with cyclohexane. Such a preparation was repeated for each sample. These samples were directly used for the qualitative, quantitative, and enantioselective analyses.

The qualitative analysis was performed by injecting $1 \mu \mathrm{L}$ of the EO solution (split 40:1) with the following thermal program. The initial oven temperature was $60^{\circ} \mathrm{C}$ for $5 \mathrm{~min}$, followed by a thermal gradient of $3{ }^{\circ} \mathrm{C} / \mathrm{min}$ up to $180^{\circ} \mathrm{C}$ and $15^{\circ} \mathrm{C} / \mathrm{min}$ up to $250^{\circ} \mathrm{C}$. The final temperature was maintained for $5 \mathrm{~min}$. The injector temperature was set at $250^{\circ} \mathrm{C}$, the carrier gas (helium) was set at $1 \mathrm{~mL} / \mathrm{min}$ (constant flow). Additionally, a mixture of $n$-alkanes $\left(C_{9}-C_{25}\right)$ was injected under the same conditions to determine the linear retention indices (LRIs).

The constituents of the essential oil were determined by comparison of mass spectra and LRIs, calculated according to van den Dool and Kratz [32], with tabulated data for DB-5ms [33] and literature for HP-INNOWax [20-31] (see Supplementary Material, Figures S3 and S4).

The quantitative analysis was performed by GC-FID, applying the same method and equipment conditions described above. Quantification was performed with external calibration curve and internal standard. Two calibration curves were obtained, injecting six dilutions of isopropyl caproate (calibration standard) and $n$-nonane (internal standard) in both columns. The dilutions were obtained by diluting $0.8 \mathrm{mg}, 1.8 \mathrm{mg}, 4.1 \mathrm{mg}, 8.3 \mathrm{mg}, 16.9 \mathrm{mg}$, and $34.5 \mathrm{mg}$ of isopropyl caproate and an exactly weighed amount of 7.6-7.8 mg of $n$-nonane to $10 \mathrm{~mL}$ with cyclohexane. All calibration curves achieved a $\mathrm{R}^{2}>$ 0.995. The relative response factor (RRF) of each constituent of the EO versus isopropyl caproate was calculated, according to combustion enthalpy [36], prior to calibration.

The enantioselective analysis was performed by GC-MS on the same samples of the qualitative and quantitative analyses, according to the following method. The initial oven temperature was 60 ${ }^{\circ} \mathrm{C}$ for $2 \mathrm{~min}$, followed by a thermal gradient of $2{ }^{\circ} \mathrm{C} / \mathrm{min}$ until $220^{\circ} \mathrm{C}$, maintained for $2 \mathrm{~min}$. Also, in this case, a mixture of $n$-alkanes $\left(\mathrm{C}_{9}-\mathrm{C}_{25}\right)$ was injected under the same conditions to calculate LRIs. The elution order of the enantiomeric pairs was determined according to literature data for the same chiral selector [37].

\section{Conclusions}

The rare sesquiterpenoid Sipaucin A was isolated for the second time from a natural source. The spectroscopic evidence for the presence of some other terpenes of the Sipaucin family in this species has been obtained.

Furthermore, the essential oil of S. echinata was qualitatively and quantitatively characterized for the first time. A total of 27 and 19 compounds were identified and quantified in a non-polar and polar column, respectively. Major compounds were $\alpha$-pinene $(24.3 \%, 20.3 \%), \beta$-pinene $(21.7 \%, 22.7 \%)$, $\beta$-myrcene $(11.3 \%, 14.8 \%)$, limonene $(10.0 \%, 11.3 \%)$, cis-ocimene $(8.5 \%, 8.1 \%)$, and trans-ocimene $(8.9 \%$, $8.4 \%)$. The enantioselective analysis performed on major monoterpenes indicated $(+)-\alpha$-pinene as enantiomerically pure and ( + )- $\beta$-pinene with $6.7 \%$ of enantiomeric excess.

Supplementary Materials: The following are available online at http://www.mdpi.com/2223-7747/9/2/187/s1, Figure S1: ${ }^{1} \mathrm{H}$ NMR $(400 \mathrm{MHz})$ spectrum of Sipaucin $\mathrm{A}$ in $\mathrm{CDCl}_{3}$. Figure S2: ${ }^{13} \mathrm{C} \mathrm{NMR}(100 \mathrm{MHz})$ spectrum of Sipaucin A in $\mathrm{CDCl}_{3}$. Figure S3: Chemical composition of Siparuna echinata essential oil on a DB-5ms column. Figure S4: Chemical composition of Siparuna echinata essential oil on a HP- INNOWax column. Table S1: ${ }^{1} \mathrm{H}$ NMR data $\left(400 \mathrm{MHz}, \mathrm{CDCl}_{3}\right)$ and ${ }^{13} \mathrm{C}$ NMR data $\left(100 \mathrm{MHz}, \mathrm{CDCl}_{3}\right)$ of Sipaucin $\mathrm{A}(1)$.

Author Contributions: Conceptualization, V.M. and G.G.; data curation, N.C., G.G. and V.M.; investigation, J.G.; methodology, V.M.; supervision, V.M.; writing — original draft, J.G; writing—review and editing, J.G. and G.G. All authors have read and agreed to the published version of the manuscript.

Funding: This research received no external funding.

Acknowledgments: We are grateful to the Universidad Técnica Particular de Loja (UTPL) for supporting this investigation and open access publication.

Conflicts of Interest: The authors declare no conflict of interest. 


\section{References}

1. Worldatlas. 17 Most Ecologically Diverse Countries on Earth. Available online: http://www.worldatlas.com/ articles/ecologically-megadiverse-countries-of-the-world.html (accessed on 10 December 2019).

2. De la Torre, L.; Navarrete, H.; Muriel, P.; Macías, M.J.; Balslev, H. Enciclopedia de las Plantas Útiles del Ecuador, Herbario QCA de la Escuela de Ciencias Biológicas de la Pontificia Universidad Católica del Ecuador y Herbario AAU del Departamento de Ciencias Biológicas de la Universidad de Aarhus. Q. Aarhus Q. Ecuad. 2008, 55.

3. Panda, S.K.; Mohanta, Y.K.; Padhi, L.; Park, Y.H.; Mohanta, T.K.; Bae, H. Large scale screening of ethnomedicinal plants for identification of potential antibacterial compounds. Molecules 2016, $21,293$. [CrossRef] [PubMed]

4. Palanichamy, P.; Krishnamoorthy, G.; Kannan, S.; Marudhamuthu, M. Bioactive potential of secondary metabolites derived from medicinal plant endophytes. Egypt. J. Basic Appl. Sci. 2018, 5, 303-312. [CrossRef]

5. Malagón, O.; Ramírez, J.; Andrade, J.M.; Morocho, V.; Armijos, C.; Gilardoni, G. Phytochemistry and ethnopharmacology of the Ecuadorian flora. A Review. Nat. Prod. Commun. 2016, 11, 297-314. [CrossRef] [PubMed]

6. Espinosa, S.; Bec, N.; Larroque, C.; Ramírez, J.; Sgorbini, B.; Bicchi, C. Chemical, enantioselective, and sensory analysis of a cholinesterase inhibitor essential oil from Coreopsis triloba S.F. Blake (Asteraceae). Plants 2019, 8, 488. [CrossRef] [PubMed]

7. Tene, V.; Malagón, O.; Finzi, P.V.; Vidari, G.; Armijos, C.; Zaragoza, T. An ethnobotanical survey of medicinal plants used in loja and zamora-chinchipe, ecuador. J. Ethnopharmacol. 2007, 111, 63-81. [CrossRef]

8. Jenett-Siems, K.; Kraft, C.; Siems, K.; Jakupovic, J.; Solis, P.N.; Gupta, M.P.; Ulrich, B. Sipaucins A-C, sesquiterpenoids from Siparuna pauciflora. Phytochemistry 2003, 63, 377-381. [CrossRef]

9. Negri, G.; de Santi, D.; Tabach, R. Chemical composition of hydroethanolic extracts from Siparuna guianensis, medicinal plant used as anxiolytics in Amazon region. Braz. J. Pharmacogn. 2012, 22, 1024-1034. [CrossRef]

10. Renner, S.S.; Won, H. Repeated evolution of dioecy from monoecy in siparunaceae (Laurales). Syst. Biol. 2001, 50, 700-712. [CrossRef]

11. Marques, C.A.; Leitão, G.G.; Bizzo, H.R.; Peixoto, A.L.; Viera, R.C. Anatomia e análise de óleo essencial das folhas de Hennecartia omphalandra. J. Poisson (Monimiaceae). Braz. J. Pharmacogn. 2009, 19, 95-105. [CrossRef]

12. González, G.; Archila, M. Anti-bacterial action of extracts and fractions from Siparuna sessiliflora Kunth A. DC (limoncillo). Rev. Cuba Plantas Med. 2012, 17, 65-72.

13. Leitão, G.G.; Simas, N.K.; Soares, S.; De Brito, A.; Claros, B.; Brito, T.; Delle, F. Chemistry and pharmacology of Monimiaceae: A special focus on Siparuna and Mollinedia. J. Ethnopharmacol. 1999, 65, 87-102. [CrossRef]

14. Leitão, G.; El-Adji, S.; Araújo, W.; Leitão, S.; Brown, L. Separation of free and glycosylated flavonoids from Siparuna guianensis by gradient and isocratic CCC. J. Liq. Chromatogr. Relat. Technol. 2005, 28, 2041-2051. [CrossRef]

15. Fischer, D.C.H.; Gualda, N.; Bachiega, D.; Carvalho, C.; Lupo, F.; Bonotto, S.V.; Alves, M.O.; Yogi, Á. In vitro screening for antiplasmodial activity of isoquinoline alkaloids from Brazilian plant species. Acta Trop. 2004, 92, 261-266. [CrossRef] [PubMed]

16. Tempone, A.G.; Treiger, S.; De Andrade, H.F.; De Amorim Gualda, N.C.; Yogi, Á.; Salerno Carvalho, C.; Bachiega, D.; Lupo, F.N.; Bonotto, S.V.; Fischer, D.C.H. Antiprotozoal activity of Brazilian plant extracts from isoquinoline alkaloid-producing families. Phytomedicine 2005, 12, 382-390. [CrossRef] [PubMed]

17. Kalemba, D.; Kunicka, A. Antibacterial and antifungal properties of essential oils. Curr. Med. Chem. 2003, 10, 813-829. [CrossRef]

18. Missouri Botanical Garden. Available online: https://www.tropicos.org/Name/21200125?tab=distribution (accessed on 12 December 2019).

19. The New York Botanical Garden. 2005. Available online: http://sweetgum.nybg.org/science/world-flora/ monographs-details/?irn=19238 (accessed on 17 December 2019).

20. Noorizadeh, H.; Farmany, A. Exploration of linear and nonlinear modeling techniques to predict of retention index of essential oils. J. Chin. Chem. Soc. 2010, 57, 1268-1277. [CrossRef]

21. Frizzo, C.D.; Serafini, L.A.; Dellacassa, E.; Lorenzo, D.; Moyna, P. Essential oil of baccharis uncinella DC. from southern Brazil. Flavour. Fragr. J. 2001, 16, 286-288. [CrossRef] 
22. Valarezo, E.; Rosales, J.; Morocho, V.; Cartuche, L.; Guaya, D.; Ojeda-Riascos, S.; Armijos, C.; González, S. Chemical composition and biological activity of the essential oil of Baccharis obtusifolia Kunth from Loja, Ecuador. J. Essent. Oil Res. 2015, 27, 212-216. [CrossRef]

23. Ruiz, S.; Malagón, O.; Zaragoza, T.; Valarezo, E. Composition of the essential oils of Artemisia sodiroi Hieron., Siparuna eggersii Hieron., Tagetes filifolia Lag. and Clinopodium nubigenum (Kunth) Kuntze from Loja Ecuador. J. Essent. Oil Bear Plants 2010, 13, 676-691. [CrossRef]

24. Neffati, A.; Skandrani, I.; Ben Sghaier, M.; Bouhlel, I.; Kilani, S.; Ghedira, K.; Neffati, M.; Chraief, I.; Hammami, M.; Chekir-Ghedira, L. Chemical composition, mutagenic and antimutagenic activities of essential oils from (Tunisian) Artemisia campestris and Artemisia herba-alba. J. Essent. Oil Res. 2008, 20, 471-477.

25. Formisano, C.; Rigano, D.; Napolitano, F.; Senatore, F. Volatile constituents of Calamintha origanifolia Boiss. growing wild in Lebanon. Nat. Prod. Commun. 2007, 2, 1253-1256. [CrossRef]

26. Ferretti, G.; Maggi, F.; Tirillini, B. Essential oil composition of Hypericum richeri Vill. from Italy. Flavour. Fragr. J. 2005, 20, 295-298. [CrossRef]

27. Naturels, P.; Belkaid, A.B.; Uvelier, L.; Sophia-antipolis, D. Composition and antibacterial activity of Pseudocytisus integrifolius (salisb.) essential oil from Algeria. J. Agric. Food Chem. 2005, 53, 2947-2952.

28. Valarezo, E.; Arias, A.; Cartuche, L.; Meneses, M.; Ojeda-Riascos, S.; Morocho, V. Biological activity and chemical composition of the essential oil from Chromolaena laevigata (lam.) R.M. King, H. Rob, (Asteraceae) from loja, ecuador. J. Essent. Oil Bear Plants 2016, 19, 384-390. [CrossRef]

29. Hachicha, S.F.; Skanji, T.; Barrek, S.; Ghrabi, Z.G.; Zarrouk, H. Composition of the essential oil of teucrium ramosissimum desf. (lamiaceae) from tunisia. Flavour. Fragr. J. 2007, 22, 101-104. [CrossRef]

30. Mancini, E.; Apostolides, N.; Martino, L.; De Feo, V.; Formisano, C.; Rigano, D.; Senatore, F. Chemical composition and phytotoxic effects of essential oils of Salvia hierosolymitana Boiss. and Salvia multicaulis Vahl. var. simplicifolia Boiss. growing wild in Lebanon. Molecules 2009, 14, 4725-4736. [CrossRef]

31. Feng, T.; Cui, J.; Xiao, Z.; Tian, H.; Yi, F.; Ma, X. Chemical composition of essential oil from the peel of Chinese Torreya grandis Fort. Org. Chem. Int. 2011, 2011, 187372. [CrossRef]

32. Van Den Dool, H.; Kratz, P.D. A generalization of the retention index system including linear temperature programmed gas-Liquid partition chromatography. J. Chromatogr. 1963, 11, 463-471. [CrossRef]

33. Adams, R.P. Identification of Essential Oil Components by Gas Chromatography/Mass Spectrometry, 4th ed.; Allured Publishing Corporation: Carol Stream, IL, USA, 2007; ISBN 10-1932633219.

34. Noriega, P.; Guerrini, A.; Sacchetti, G.; Grandini, A.; Ankuash, E.; Manfredini, S. Chemical composition and biological activity of five rain forest. Molecules 2019, 24, 1637. [CrossRef]

35. Bulow, N.; Konig, W. The role of germacrene D as a precursor in sesquiterpene biosynthesis: Investigations of acid catalyzed, photochemically and thermally induced rearrangements. Phytochemistry 2000, 55, 141-168. [CrossRef]

36. Tissot, E.; Rochat, S.; Debonneville, C.; Chaintreau, A. Rapid GC-FID quantification technique without authentic samples using predicted response factors. Flavour. Fragr. J. 2012, 27, 290-296. [CrossRef]

37. Gilardoni, G.; Ramírez, J.; Montalván, M.; Quinche, W.; León, J.; Benítez, L.; Morocho, V.; Cumbicus, N.; Bicchi, C. Phytochemistry of three ecuadorian lamiaceae: Lepechinia heteromorpha (briq.) epling, Lepechinia radula (Benth.) Epling and Lepechinia paniculata (kunth) epling. Plants 2019, 8, 1. [CrossRef] [PubMed]

(C) 2020 by the authors. Licensee MDPI, Basel, Switzerland. This article is an open access article distributed under the terms and conditions of the Creative Commons Attribution (CC BY) license (http://creativecommons.org/licenses/by/4.0/). 